\title{
Examination of Science and Math Course Achievements of Vocational High School Students in the Scope of Self-efficacy and Anxiety
}

\author{
Mehmet Yüksel ${ }^{1}$, Ömer Geban ${ }^{2}$ \\ ${ }^{1}$ Yenimahalle Alparslan Anatolian High School, Yenimahalle, Ankara, Turkey \\ ${ }^{2}$ Middle East Technical University, Faculty of Education, Çankaya, Ankara, Turkey \\ Correspondence: Mehmet Yüksel, Yenimahalle Alparslan Anatolian High School, Yenimahalle, Ankara, Turkey
}

Received: September 14, 2015

Accepted: September 28, $2015 \quad$ Online Published: October 9, 2015

doi:10.11114/jets.v4i1.1090

URL: http://dx.doi.org/10.11114/jets.v4i1.1090

\begin{abstract}
This study attempted to predict physics, chemistry, and biology and math course achievements of vocational high school students according to the variables of student self-efficacy, academic self-efficacy, state anxiety and trait anxiety. Study data were collected using a questionnaire administered to the students of a vocational high school located in Ankara, the capital city of Turkey. According to the results of the study, academic self-efficacy perceptions of students predicted achievement in physics, chemistry and math courses. Achievement in biology course, on the other hand, was predicted by student self-efficacy. When the results were examined according to the anxiety variable, trait anxiety was detected to predict physics course achievement and state anxiety to predict math course achievement. Study results showed that types and effects of anxiety and self-efficacy variables vary depending on the characteristics and nature of courses.
\end{abstract}

Keywords: Academic achievement, Academic self-efficacy, Student self-efficacy, State-Trait Anxiety, Vocational high school

\section{Introduction}

As the case in the rest of the world(Shavit, \& Muller, 2000), among the educational institutions at secondary education level in Turkey, vocational secondary high schools are deemed important as they train qualified labor force directly for industrial and economic development of the country. In addition, these educational institutions train students for undergraduate education following secondary education. However, although faced in all training programs offered at secondary education level in Turkey (Durmuşçelebi \& Bilgili, 2014), the problems encountered in vocational and technical training programs are more common and heavy (Sönmez, 2008). The most important problem of these educational institutions is the issue of academic achievement. As a matter of fact, vocational secondary high schools are observed to be less successful than other secondary high schools in the transition to higher education examinations made every year at national level by the student selection and the placement centre (ÖSYM, 2014). Although the fact of academic achievement is related to high number of variables (Bulach, Malone, \& Castleman, 1995; Ferla, Valcke, \& Schuyten, 2010; Hejazi, Rouxel, 1999; Shahraray, Farsinejad, \& Asgary, 2009; Weiser \& Riggio, 2010), it is impossible to consider this fact in isolation from the student her/himself or her/his personality traits or character (Gilles \& Bailleux, 2001; Lounsbury, Fisher, Levy, \& Welsh, 2009). In the early studies aimed at explaining academic achievement over the subject of student, it is seen that interest and expectations are focused on cognitive factors (Adebayo, 2008; Dalgety \& Coll, 2006). However, it is understood from the related studies that academic achievement is a multi-dimensional having a structure that cannot be explained only by cognitive factors. Thus, the fact of academic achievement has been recently studied in the context of affective perception and characteristics of students (Fettahlıoglu, Güven, İnce Aka, Sert Çıbık, \& Aydoğdu, 2011; Komarraju \& Nadler 2013; Zajacova, Lynch, \& Espenshadet, 2005). The main reason behind this trend is the detection that affective domain factors as well as cognitive domain factors are affective on explaining student achievement (Şahin, Gülay Ogelman, \& Ekici, 2011).

It is seen that there are high number of affective variables in the literature, which are used in explanation or prediction of academic achievement (Sikhwari, 2007). Failure of cognitive variables to sufficiently explain academic achievement and the new variables thought to may have efficient role in explaining academic achievement also constitute subjects of studies. Indeed, one of the affective variables used in explaining academic achievement is the fact of self-efficacy. 
Actually, the fact of self-efficacy is not a quite new concept. Expressed for the first time by Bandura (1977), the concept of self-efficacy is defined as "people's beliefs about their capabilities to produce designated levels of performance that exercise influence over events that affect their lives" (Bandura, 1994:71). The fact of self-efficacy indicates individual's belief in what he can achieve by using his capabilities under different situations and conditions (Sak1z, 2013). For this reason, as stated by Zimmerman (2000), self-efficacy belief has a multi-dimensional disposition. Self-efficacy concept is classified in literature in different ways, taking as basis the target individual and her/his related life section (Yeşilyurt, 2013). In education, when considered from the point of students, there are course-oriented self-efficacy classifications (Sakız, 2013); however, self-efficacy concept is observed to be classified as academic self-efficacy and student self-efficacy at general level.

Landry (2003:73) expressed student self-efficacy as "students' strengths of self-efficacy beliefs". This concept consists of the dimensions of "self-efficacy for self-regulated learning, self-efficacy for academic achievement, financial attitudes/difficulties, and career decision-making" (Landry, 2003:73-74). Self-efficacy has been detected to positively affect academic achievement in the studies on undergraduates (Fettahlığlu et al., 2011; Komarraju \& Nadler 2013; Zajacova et al., 2005) and high school students (Çikrıkçi \& Odac1, 2013; Diseth, 2011; Yazıc1, Seyis, \& Altun 2011; Hampton \& Mason, 2003 ). However, the extent to which self-efficacy variable affects academic achievement and the capability of the former to explain the latter varies. Being another type of self-efficacy concept, academic self-efficacy is defined as "students' confidence in their ability to carry out such academic tasks as preparing for exams and writing term papers" (Zajacova et al., 2005). Studies have also been conducted to examine academic achievement in the context of academic self-efficacy which reflects academic dimension of self-efficacy. Academic self-efficacy has been detected to be an affective variable on academic achievement in the studies conducted on undergraduates (Abd-Elmotaleb \& Saha, 2013; Şahin et al., 2011; Yaratan \& Suphi, 2012) and high school students (Akomolafe, Ogunmakin, \& Fasooto, 2013). The ability of academic self-efficacy variable to explain academic achievement has also been found to vary, as the case in self-efficacy variable.

Anxiety, another affective variable, is observed to be addressed by the studies aimed at explaining academic achievement (Heinrich, 1979; Büyüköztürk, 1997). Anxiety is explained in most general terms as the state of fear and tension activated under threat (Büyüköztürk, 1997). In general context, anxiety is classified into state anxiety and trait anxiety. State anxiety is the feeling threatening present situation of the individual and resulting, for this reason, in danger perception by the individual (Civan, Özdemir, Taş, \& Çelik, 2012). State anxiety is regarded a transitory emotional state including the feelings of subjective tension and fear (Büyüköztürk, 1997). On the other hand, trait anxiety is regarded a personal trait (Civan et al., 2012). Trait anxiety shows individual's anxiety tendency inherent in her/his nature (Büyüköztürk, 1997).

It is seen that academic achievement is addressed in the literature in the context of different anxiety types. Studies on undergraduates (Nadeem, Ali, Maqbool, \& Zaidi, 2012; Singh \& Jha, 2013) have shown that there is a negative correlation between anxiety and academic achievement and that academic achievement decreases when anxiety increases. On the other hand, the studies made in the context of anxiety types (McEwan \& Goldenberg, 1999; Yokuş, 2013) have revealed a negative correlation between state anxiety and academic achievement of undergraduates. However, another study on undergraduates (Dereli, Angın, \& Karakuş, 2012) found no relationship between state anxiety and academic achievement. This conflicting situation applies also for trait anxiety variable. There are also some literature studies suggesting positive correlation between trait anxiety and academic achievement (McEwan \& Goldenberg, 1999). Contrarily, some studies (Okur \& Bahar, 2010; Dereli et al., 2012; Yokuş, 2013) have shown that there is no relationship between trait anxiety level and academic achievement and that the former is not a meaningful predictor of the latter. There are also some literature studies analyzing anxiety variable in the context of a specific field anxiety. For instance, in a study on second language learners (Zin \& Rafik-Galea, 2010), a negative correlation was detected between reading anxiety and reading performance. In another study (Mohammadyari, 2012), a similar negative correlation was found between test anxiety and academic achievement. Test anxiety was detected to be an important predictor of academic achievement. In their study on high school students, Akbaş \& Kan (2007) found anxiety to be a variable predicting achievement in chemistry course. In their study on undergraduates, Kurbanoğlu \& Akim (2010) found a negative correlation between chemistry laboratory anxiety and self-efficacy.

Although the literature studies explaining academic achievement in the context of student self-efficacy, academic self-efficacy and state-trait anxiety variables have produced important findings, there is still a number of issues need to be answered. First of these issues is the limitation resulting from addressing academic achievement generally as a whole (Diseth, 2011; Şahin et al., 2011; Yazıcı et al., 2011; Abd-Elmotaleb \& Saha, 2013; Çikrıkçi \& Odacı, 2013; Komarraju \& Nadler, 2013). Existing literature studies have generally considered general academic achievement as "grade point average". General academic achievement of a student is important, but her/his interest and efficacy in the related field is also an important issue. Due to its decomposition, the relationship between self-efficacy variable (Kondakci, Aydin, 
Kirbulut, \& Beeth, 2011) and academic achievement may change depending on the features and characteristics of courses. For instance, while student self-efficacy can be determinant in achievement in biology course, academic self-efficacy perception may be more important in achievement in chemistry or physics course. For this reason, it is important to consider these possible differences when examining academic achievement from the aspects of self-efficacy and anxiety variables. However, no study has been found in the literature, which can be deemed sufficient in explaining field- or course-based academic achievement in the context of self-efficacy, academic self-efficacy, state and trait anxiety. In the study conducted by Kan \& Akbaş (2006) on high school students, one of the limited numbers of studies in this scope, self-efficacy was detected to be one of the variables predicting achievement in chemistry course. In Tenaw's (2013) study on students attending at Debre Markos College of Teacher Education, the relationship between self-efficacy and achievement was studied only in the context of Analytical Chemistry I. Concerned study detected a positive correlation between the two variables. In their study aimed at revealing math achievement of the secondary education students in Argentina in the context of Social Cognitive Career Theory; Cupani, Richaud de Minzi, Perez \& Pautassi (2010) found a positive correlation between the logical-mathematical self-efficacy and math performance. In the study by Çetin-Dindar \& Geban (2011) on eleventh grade high school students, self-efficacy was detected to be a variable predicting achievement in chemistry course. In another study (Fettahlıoğlu et al., 2011), undergraduates' self-efficacy beliefs in science education was found to positively predict at a significant level the academic achievement in the subject of "body systems". On the other hand, studies on anxiety are observed to address academic achievement generally as grade point average (McEwan \& Goldenberg, 1999; Okur \& Bahar, 2010; Yokuş, 2013). There are also some literature studies conducted, in the context of a specific field, on second language learning (Zin \& Rafik-Galea, 2010) and the relationship between chemistry anxiety and chemistry course (Akbaş \& Kan, 2007).

Another issue not answered by the literature yet is the direction and level of the role of self-efficacy, academic self-efficacy, state and trait anxiety variables in the academic achievement of the students attending at vocational high schools which are more application-oriented compared to other types of high schools. Among the literature studies covering students of different school types, no study has been found to sample vocational high school students. However, previous studies state that students' anxiety (Kurbanoğlu \& Takunyac1, 2012) and self-efficacy perceptions may differ depending on school type (Sezer, İşör, Özpolat \& Sezer, 2006). As a matter of fact, in a study on secondary education students (Sezer et al., 2006), self-efficacy perceptions and levels of students attending at schools selecting students by examination and according to their skills were found to be higher than those of students attending at general high schools. In a study on math course (Kurbanoğlu \& Takunyac1, 2012), a statistically significant difference was found between anxiety, attitude and self-efficacy believes of students depending on school type. Self-efficacy believes of the students attending at Anatolian High Schools among all school types were seen to be higher, their math anxiety level to be lower and math attitudes to be higher than the students of other types of high schools. These findings support the results of the previous study. For this reason, effects of self-efficacy and anxiety facts, which are deemed important in predicting academic achievement, may vary depending on school type.

There are literature studies to have separately addressed each variable, included in the scope of the present study, in terms of their effects on academic achievement or their predictability of academic achievement. As a result of these studies, self-efficacy and academic self-efficacy perceptions have been found to be variables separately predicting academic achievement. However, no study has been encountered aimed at determining relatively the level at which self-efficacy and academic self-efficacy variables together effect achievement. In the present study, a similar relationship was also considered for the effects of state and trait anxiety variables on academic achievement. In other words, this study addressed the issue of which anxiety type is predictor on academic achievement.

Another dimension of the present study, which can be deemed unique, is that it addressed self-efficacy variable -which is assumed to facilitate achievement- and (Sak1z, 2013) anxiety variable -which has negative effects on achievementtogether. Addressing of anxiety and self-efficacy belief together is important also from the aspect that anxiety is the source of self-efficacy fact (Sakiz, 2013). Self-efficacy can be both antecedent and result for physiological and psychological state. While low self-efficacy perception may result in negative moods such as anxiety and stress, these moods may also be seen as indications of low self-efficacy (Sakız, 2013). It is important to examine the effects of this bidirectional relationship between the two variables on academic achievement. In order to define the roles of these variables, it is necessary to detect the level of relative importance of these variables which have positive and negative effects on academic achievement. Literature review showed that Kemer (2006) examined anxiety and self-efficacy variables together from academic achievement aspect. However, Kemer's study (2006) addressed the role of anxiety and self-efficacy variables on predicting university entrance examination scores of students in Turkey. Reactions and perceptions of students towards anxiety and self-efficacy variables in the university entrance examination process, which is a different type of examination due to its structure, can be suggested to possibly differ from those of the students still in high school period. For this reason, contribution to generalization of the explanations about the level 
and direction of the relationship between academic achievement and the variables can only be possible via studies to be conducted in the context of courses.

In the light of the information given above, main purpose of this study was set as to predict achievement in physics, chemistry, biology and math courses of the vocational high school students according to the variables of self-efficacy, academic self-efficacy, state-trait anxiety.

\section{Method}

\subsection{Study Model}

In this study, firstly examined the correlation between the achievement in physics, chemistry, biology and math courses, on one hand, and academic self-efficacy, study self-efficacy, state anxiety and trait anxiety variables, on the other hand. Secondly, academic achievement -as the dependent variable- was attempted to be predicted via multiple regression analysis by the independent variables of academic self-efficacy, student self-efficacy, and state anxiety and trait anxiety.

\subsection{Sample}

The sample of this study was constituted by the students to have attended at a vocational high school in Ankara, the capital city of Turkey. Two hundred and ten (210) of 914 students taking math, physics, chemistry and biology courses were selected for the study using convenience sampling method. However, data collected from totally 207 students were evaluated in data analyses process due to the failure of the remaining 3 students to fill the questionnaire completely.

\subsection{Data Collection Instruments}

In the scope of the study, academic achievement of the students in physics and math courses were determined using school records. Original form of the academic self-efficacy questionnaire used in the study is developed by Owen \& Froman (1988). Studies to adapt the questionnaire into Turkish were performed by Kemer (2006). Academic self-efficacy questionnaire consists of 33 items. Questionnaire items were measured using 5-point Likert-type scale. Kemer (2006) examined structural validity of the questionnaire via factor analyses and the items of the academic self-efficacy questionnaire were stated to be organized under six factors and these factors to explain $47 \%$ of the total variance. Kemer (2006) also analyzed internal consistency of the questionnaire and achieved a Cronbach's Alpha coefficient of 0.87. In another study conducted using the same questionnaire (Altun \& Yazıc1, 2012), Cronbach's Alpha coefficient was found to be 0.95 . In the present study, on the other hand, Cronbach's Alpha reliability coefficient of the academic self-efficacy questionnaire was calculated to be 0.904 .

Studies on adaptation into Turkish of the student self-efficacy questionnaire used in the present study were also conducted by Kemer (2006). Original form of the questionnaire is developed by Landry (2003). The questionnaire consists of 32 items. Questionnaire items were measured using 5 point Likert-type scale. Kemer (2006) examined structural validity of the student self-efficacy questionnaire using factor analyses and found that items were organized under five factors. The ability of these factors to explain total variance was found to be $49 \%$. However, in his reliability analyses, Kemer (2006) achieved a Cronbah's Alpha coefficient of 0.87. In the present study, on the other hand, Cronbah's Alpha reliability coefficient was calculated to be 0.910 .

The present study measured state and trait anxiety variables using the State-Trait Anxiety Inventory developed by Spielberger, Gorsuch \& Lushene (1970). The inventory consists of two 20-item questionnaires, one for state anxiety and the other for trait anxiety (Öner \& Le Compte, 1985). The items of the state anxiety questionnaire are scored 1-4 points. Ten (10) out of 20 items of the state anxiety questionnaire are structured as reverse statements. Similarly, the items of the trait anxiety questionnaire are scored 1-4 points. Seven (7) out of 20 items of the trait anxiety questionnaire are structured as reverse statements. In their study, Öner \& Le Compte (1985) calculated questionnaire reliability as 0.83-0.87 for Trait Anxiety Questionnaire and as 0.94 - 0.96 for State Anxiety Questionnaire. During the literature review, state and trait anxiety questionnaires were detected not only to have been used in studies conducted on the sampling groups sharing similar demographic characteristics with the sampling group of the present study (Akar, Dağ Akpolat, \& Miman, 2014; Kemer, 2006) but also to have achieved high reliability levels. In the present study, Cronbach's Alpha reliability coefficient of the State Anxiety Questionnaire was calculated to be 0.921 and of the Trait Anxiety Questionnaire to be 0.877 .

\subsection{Data Analyses}

SPSS 18.0 package program was used in the study for statistical analysis. Firstly, One-Sample Kolmogorov-Smirnov Test was used to analyze compliance with normal distribution of the academic self-efficacy, student self-efficacy, state anxiety and trait anxiety scores. Distributions of the variable scores were found to be normal according to the values obtained at the end of the analysis (Table 1). 
Table 1. One-Sample Kolmogorov-Smirnov Test

\begin{tabular}{llllll}
\hline Variables & \multirow{2}{*}{ Average } & $\begin{array}{l}\text { Standard } \\
\text { Deviation }\end{array}$ & $\begin{array}{l}\text { Kolmogrov-Smirnov } \\
\text { Z value }\end{array}$ & $\begin{array}{l}\text { Significance } \\
(\mathrm{p})\end{array}$ \\
\hline Academic self-efficacy & 207 & 110.50 & 19.22 & 0.466 & 0.982 \\
Student self-efficacy & 207 & 110.86 & 18.89 & 0.704 & 0.705 \\
State anxiety & 207 & 40.77 & 12.37 & 1.172 & 0.128 \\
Trait anxiety & 207 & 42.01 & 9.78 & 1.019 & 0.250 \\
\hline
\end{tabular}

Before data analysis, Test of Homogeneity of Variances was also performed in the scope of the study in order to test homogeneity of the grade-based academic self-efficacy, student self-efficacy, state anxiety and trait anxiety scores of the students. The analysis revealed a normal distribution for the grade-based variables. Results of the One-Sample Kolmogorov-Smirnov Test and Test of Homogeneity of Variances proved usability of parametric tests in this study (Table 2).

Table 2. Test of Homogeneity

\begin{tabular}{llll}
\hline Variables & Levene's Statistics & $\begin{array}{l}\text { Degree of Freedom } \\
(\mathrm{df} 1 / \mathrm{df} 2)\end{array}$ & $\begin{array}{l}\text { Significance } \\
(\mathrm{p})\end{array}$ \\
\hline Academic self-efficacy & 1.497 & $3 / 203$ & 0.216 \\
Student self-efficacy & 1.109 & $3 / 203$ & 0.347 \\
State anxiety & 1.092 & $3 / 203$ & 0.353 \\
Trait anxiety & 0.581 & $3 / 203$ & 0.628 \\
\hline
\end{tabular}

\section{Results}

Correlations between study variables were detected using Pearson correlation analysis. As seen in Table 3, there is a statistically significant $(\mathrm{p}<0.01)$ and almost high positive correlation between the variables of academic self-efficacy and student self-efficacy. Correlation between academic self-efficacy and state and trait anxiety variables is also statistically significant $(\mathrm{p}<0.01)$ and negative. Correlation between academic self-efficacy and achievement in math, physics, chemistry and biology courses was found to be positive $(\mathrm{p}<0.01)$, while the correlation between student self-efficacy and state and trait anxiety variables to be negative $(\mathrm{p}<0.01)$. Correlation between student self-efficacy and achievement in math, physics, chemistry and biology courses was revealed to be positive $(\mathrm{p}<0.01)$. However, correlation between state and trait anxiety and academic achievement variables was found to be statistically insignificant $(\mathrm{p}>0.05)$.

Table 3. Pearson's Correlation Coefficients between Variables

\begin{tabular}{lllllllll}
\hline \multicolumn{1}{c}{ Variables } & 1 & 2 & 3 & 4 & 5 & 6 & 7 & 8 \\
\hline 1. Academic self-efficacy & 1 & $.833^{*}$ & $-.455^{*}$ & $-.437^{*}$ & $.336^{*}$ & $.357^{*}$ & $.368^{*}$ & $.308^{*}$ \\
2. Student self-efficacy & & 1 & $-.443^{*}$ & $-.422^{*}$ & $.283^{*}$ & $.303^{*}$ & $.320^{*}$ & $.310^{*}$ \\
3. State anxiety & & & 1 & $.737^{*}$ & -.100 & -.021 & -.108 & -.114 \\
4. Trait anxiety & & & & 1 & -.072 & -.038 & -.037 & -.063 \\
5. Chemistry achievement & & & & & 1 & $.701^{*}$ & $.618^{*}$ & $.605^{*}$ \\
6. Math achievement & & & & & & 1 & $.655^{*}$ & $.579^{*}$ \\
7. Physics achievement & & & & & & & 1 & $.604^{*}$ \\
8. Biology achievement & & & & & & & 1 \\
\hline
\end{tabular}

* Statistically significant at $\mathrm{p}<0.01$ level (2- tailed)

After detection of the correlations between study variables, it was attempted to define the variables predicting achievement in math, physics, chemistry and biology courses. To this end, academic self-efficacy, student self-efficacy, state anxiety and trait anxiety were included in the regression model as independent variables.

Examination of the results of stepwise regression analyses made to detect achievement in physics course (Table 4) shows that academic self-efficacy and trait anxiety are the variables predicting achievement in physics course. The ability of these two variables, included in the model, to explain academic achievement is $0.154(\mathrm{~F}(2,204)=18.621, \mathrm{p}<$ $0.001, \mathrm{R} 2=0.154$, Corrected R2 $=0.146)$. 
Table 4. Variables Predicting Academic Achievement in Physics, Chemistry, Biology and Mathematics Course According to Stepwise Regression Analysis Results

\begin{tabular}{|c|c|c|c|c|c|c|c|c|c|c|}
\hline & \multicolumn{3}{|c|}{ Physics } & \multicolumn{2}{|c|}{ Chemistry } & \multicolumn{2}{|c|}{ Biology } & \multicolumn{3}{|c|}{ Mathematics } \\
\hline & Cons. & ASE & TA & Cons. & ASE & Cons. & SSE & Cons. & ASE & SA \\
\hline $\begin{array}{l}\text { Unstandardized } \\
\text { Coefficients (B) }\end{array}$ & 3.031 & 0.344 & 0.238 & 32.402 & 0.235 & 31.974 & 0.236 & -2.481 & 0.421 & 0.266 \\
\hline Standard Error & 9.351 & 0.057 & 0.111 & 5.165 & 0.046 & 5.675 & 0.050 & 10.553 & 0.070 & 0.108 \\
\hline B & & 0.435 & 0.153 & & 0.336 & & 0.310 & & 0.437 & 0.178 \\
\hline $\mathrm{t}$ & 0.324 & 6.076 & 2.141 & 6.274 & 5.105 & 5.634 & 4.672 & -0.235 & 6.041 & 2.453 \\
\hline Significance (p) & 0.877 & 0.000 & 0.033 & 0.000 & 0.000 & 0.000 & 0.000 & 0.814 & 0.000 & 0.015 \\
\hline
\end{tabular}

Cons: constant, ASE Academic self-efficacy, SSE Student self-efficacy, SA State anxiety, TA Trait anxiety

Since student self-efficacy and trait anxiety were found to be statistically insignificant, they were excluded from the model. In the light of the examination of this situation in statistical terms, it can be suggested that the reason behind statistical insignificance of student self-efficacy and trait anxiety in predicting academic achievement in physics course is the almost high correlation between the variables (Table 3). Among the academic self-efficacy and student self-efficacy variables and state anxiety and trait anxiety variables, which were highly correlated between each other, the variable having relatively lower effect on academic achievement is observed to be excluded from the model. Academic self-efficacy and trait anxiety -the two variables found to have higher effect on academic achievementremained in the stepwise regression model as two meaningful variables. To clarify this thought, a second multiple regression analysis was made in the scope of the study (Table 5). In this analysis, only the student self-efficacy and state anxiety variables, the only variables which were found insignificant by the previous model, were included in the model at the beginning as independent variables. At the end of the analysis, only student self-efficacy was detected to be a statistically significant variable in predicting academic achievement in physics course. State anxiety, of the other hand, was observed to be a statistically insignificant predictor variable, as in the previous stepwise regression analysis model. The ability of the model, where student self-efficacy variable was found to be significant, to explain academic achievement in physics course is $10.4 \%\left(\mathrm{R}^{2}=0.104\right.$; Corrected $\left.\mathrm{R}^{2}=0.95 ; \mathrm{F}=11,860 ; \mathrm{p}<0.001\right)$. Multiple regression analysis findings were observed to confirm the result produced by the almost high correlation between academic self-efficacy and student self-efficacy. In other words, inclusion of academic self-efficacy variable in and exclusion of student self-efficacy variable from the previous stepwise regression analysis model mainly resulted from relatively higher effect of academic self-efficacy variable. However, it is impossible to draw a similar conclusion for state anxiety variable. In other words, exclusion of state anxiety variable from the stepwise regression analysis model did not result from relatively higher influence of trait anxiety variable compared to state anxiety variable. Rather, state anxiety is understood to be excluded from the model since it is not a predictor variable of academic achievement in physics course.

Table 5. Variables Effective on Academic Achievement in Physics, Chemistry, Biology and Mathematics Course According to Multiple Regression Analysis Results

\begin{tabular}{|c|c|c|c|c|c|c|c|c|c|c|c|c|c|c|}
\hline & Physics & & & Chemis & & & & Biology & & & & Math & & \\
\hline & Cons. & SSE & SA & Cons & SSE & SA & TA & Cons. & ASE & SA & TA & Cons. & SSE & TA \\
\hline $\begin{array}{l}\text { Unstandardized } \\
\text { Coefficients (B) }\end{array}$ & 18.644 & 0.273 & 0.052 & 31.103 & 0.217 & -0.016 & 0.093 & 25.030 & 0.253 & -0.059 & 0.180 & 8.183 & 0.343 & 0.208 \\
\hline Standard Error & 8.927 & 0.059 & 0.091 & 8.835 & 0.054 & 0.111 & 0.139 & 9.342 & 0.057 & 0.117 & 0.147 & 11.736 & 0.072 & 0.139 \\
\hline B & & 0.339 & 0.043 & & 0.304 & -0.015 & 0.067 & & 0.338 & $\begin{array}{l}- \\
0.051\end{array}$ & 0.122 & & 0.350 & 0.110 \\
\hline $\mathrm{t}$ & 2.089 & 4.591 & 0.576 & 3.520 & 4.010 & -0.144 & 0.668 & 2.679 & 4.466 & -0.502 & 1.225 & 0.697 & 4.778 & 1.501 \\
\hline Significance (p) & 0.038 & 0.000 & 0.566 & 0.001 & 0.000 & 0.886 & 0.505 & 0.008 & 0.000 & 0.616 & 1.225 & 0.486 & 0.000 & 0.135 \\
\hline
\end{tabular}

Cons: constant, ASE Academic self-efficacy, SSE Student self-efficacy, SA State anxiety, TA Trait anxiety

Results of the stepwise regression analysis made to define the variables predicting achievement in chemistry course are listed in Table 4. The only variable included in the regression analysis model predicting achievement in chemistry course is academic self-efficacy. According to the model, the ability of academic self-efficacy variable to explain chemistry achievement is $0.113(\mathrm{~F}(1,205)=26.060, \mathrm{p}<0.001, \mathrm{R} 2=0.113$, Corrected $\mathrm{R} 2=0.108)$.

Other variables were found to be statistically insignificant $(\mathrm{p}>0.05)$ and excluded from the model. The reason behind 
this finding was examined statistically. In other words, the reason behind inclusion of only academic self-efficacy variable in the stepwise regression analysis model was attempted to be explain by multiple regression analysis. To this end, firstly, the analysis was made before inclusion in the model of the academic self-efficacy variable, which is highly correlated with student self-efficacy variable and which is included in the stepwise regression model (Table 4). At the end of the analysis, student self-efficacy variable was observed to be the variable predicting chemistry achievement (Table 5). This finding showed that student self-efficacy and academic self-efficacy variables were correlated at an almost high level; that academic self-efficacy had relatively higher influence on academic achievement in chemistry course, compared to student self-efficacy; and that, for this reason, student self-efficacy was not included in the stepwise regression model. On the other hand, state anxiety and trait anxiety are seen to be the two variables which do not predict achievement in chemistry course at a statistically significant level. As a matter of fact, the result produced by the stepwise regression analysis model complies with these findings. The ability of student self-efficacy, the variable included in the model, to explain academic achievement in chemistry course is $0.083(\mathrm{~F} 3,203)=6,094, \mathrm{p}<0.001, \mathrm{R} 2=$ 0.083, Corrected R2 $=0.069$ ).

Variables predicting achievement in biology course were defined using stepwise regression analysis as well. As seen in Table 4, the variable predicting achievement in biology course was found to be student self-efficacy. Other variables were recorded to be statistically insignificant $(\mathrm{p}>0.05)$ and excluded from the model. According to stepwise regression model, the ability of the student self-efficacy variable to explain biology achievement is $0.096(\mathrm{~F}(1,205)=21.828, \mathrm{p}<$ 0.001, R2 = 0.096, Corrected R2 = 0.092).

The reason behind exclusion of other variables from the model was attempted to be explained in statistical terms. To this end, the variables other than student self-efficacy variable were included in the multiple regression analysis model (Table 5). At the end of the analysis, academic self-efficacy was found to be the meaningful variable predicting academic achievement in biology course. This finding shows that the high correlation between academic self-efficacy and student self-efficacy variables in predicting academic achievement in biology course excluded from the stepwise regression model the variable with relatively lower effect. State and trait anxiety variables, on the other hand, were detected to be ineffective in predicting academic achievement in biology course, as shown by the findings of stepwise regression analysis. The ability of the regression model (Table 5), where academic self-efficacy was statistically significant, to explain academic achievement in biology course is $0.102(\mathrm{~F}(3,203)=7,709, \mathrm{p}<0.001, \mathrm{R} 2=0.102$, Corrected R2 = 0.089).

In the scope of the study, the variables predicting achievement in math course were also defined using stepwise regression analysis (Table 4). At the end of the analysis, academic self-efficacy and state anxiety were determined to be the variables predicting math achievement. According to the stepwise regression model, the ability of academic self-efficacy and state anxiety variables to explain math achievement is $0.152(\mathrm{~F}(2,204)=18.300, \mathrm{p}<0.001, \mathrm{R} 2=$ 0.152 , Corrected R2 $=0.144$ ).

Other variables not predicting achievement in math course were analyzed by a second analysis. To this end, academic self-efficacy and state anxiety variables -which were included in the stepwise regression analysis model- were excluded from the multiple regression analysis model used to detect predictor variables. In this parallel, student self-efficacy and trait anxiety variables were subjected to multiple regression analysis. At the end of the analysis, student self-efficacy variable was found to be a statistically significant predictor (Table 5). This finding shows that student self-efficacy is a variable in high correlation with academic self-efficacy and that in an analysis containing both variables, the former is excluded from and the latter is included in the model due to the relatively higher importance of the latter. However, no similar result was obtained for trait anxiety. In other words, trait anxiety was found to be a statistically insignificant variable in predicting academic achievement, either itself or together with state anxiety. According to the multiple regression analysis, the ability of the model (which includes student self-efficacy variable predicting academic achievement in math course) to explain academic achievement is $0.102(\mathrm{~F}(2,204)=11.574, \mathrm{p}<0.001, \mathrm{R} 2=0.102$, Corrected R2 = 0.093).

\section{Discussion}

Examination of the study results from the aspect of relationship between affective variables revealed a negative correlation between state and trait anxiety and academic self-efficacy and student self-efficacy. This result shows that student's state and trait anxiety decreases when her/his academic self-efficacy and student self-efficacy increases and vice versa, i.e., student's self-efficacy perception decreases when her/his state and trait anxiety increases. This relationship which was detected by the present study is a fact that can be explained by the nature of variables. As a matter of fact, in the studies explaining self-efficacy fact within the theoretical framework (Bandura, 1977; Bandura, 1994), content and components of self-efficacy fact are stated to aim strengthening of individual's belief in achievement. Therefore, a self-efficacy perception including high achievement belief can be suggested to enable the individual to tend 
to feel a lower level of anxiety. Similar results have been produced by the empirical literature studies as well (Carberry, Lee, \& Ohland, 2010).

Examination of study results from the aspect of general academic achievement revealed a positive correlation between self-efficacy and academic achievement. This result complies with the results of previous literature studies (Hampton \& Mason, 2003; Zajacova et al., 2005; Fettahlığlu et al., 2011; Diseth, 2011; Yazıcı et al., 2011; Çikrıkçi \& Odacı, 2013; Komarraju \& Nadler, 2013). Another result parallel with the findings of the previous literature studies (Şahin et al., 2011; Yaratan \& Suphi, 2012; Abd-Elmotaleb \& Saha, 2013; Akomolafe et al., 2013) is the positive correlation between academic self-efficacy variable and academic achievement. Positive correlation of academic achievement with self-efficacy and academic self-efficacy variables can be suggested to be important for the planning and implementation works of education and training processes. For instance, the role of these variables can be utilized in sustaining, controlling, and increasing the achievement of the students' academic studies.

The study found a positive correlation between student self-efficacy, on one hand, and the achievement in math, physics, chemistry and biology courses, on the other. Indeed, this is not a surprising relationship in terms of the characteristics of the variables. In addition, this result has similarities with the results of the previous literature studies (Li, 2012; Y1lmaz, Yiğit, \& Kaşarc1, 2012; Mohammadyari, 2012; Loo \& Choy, 2013; Çikrıkçi \& Odac1, 2013; Shkullaku, 2013; Tenaw, 2013). Moreover, a positive correlation was also detected between academic self-efficacy, on one hand, and the achievement in math, physics, chemistry and biology courses, on the other. There are also other literature studies stating a positive correlation between academic self-efficacy and academic achievement (Şahin et al., 2011; Yaratan \& Suphi, 2012). This relationship shows that a student with high academic self-efficacy perception may be quite successful in courses as well. On the contrary, students with low academic self-efficacy perception will succeed low course achievement. This relationship can be explained with the efficacy perception of academic elements included in the structure of academic self-efficacy perception.

State anxiety and trait anxiety, other affective variables of the study, were found to have insignificant correlation with achievement in math, physics, and chemistry and biology courses. This result does not mean that there is no relationship between academic achievement and anxiety or the types of anxiety. While this result has similarities with those of some literature studies, it conflicts with those of some other literature studies. As a matter of fact, there are literature studies stating a negative correlation between anxiety and academic achievement (Zin \& Rafik-Galea, 2010; Nadeem et al., 2012; Mohammadyari, 2012; Yokuş, 2013; Singh et al., 2013). However, some other literature studies (Heinrich, 1979; McEwan \& Goldenberg, 1999; Dereli et al., 2012) found no relationship between state anxiety and academic achievement. In the study by Yokuş (2013), on the other hand, a negative correlation was detected between academic achievement and state anxiety. In addition, some literature studies (Heinrich, 1979; McEwan \& Goldenberg, 1999) stated a positive relationship between trait anxiety and academic achievement. However, contrarily, some other studies (Dereli et al., 2012; Yokuş, 2013) found no significant relationship between academic achievement and trait anxiety.

As is seen, studies addressing the relationship of anxiety or the types of anxiety with academic achievement have produced different results. These conflicting results can be explained as follows: First of all, these results can be suggested to result from the structure and content of anxiety variable because anxiety or the types of anxiety, by their nature, constitute a variable closely related to the personal traits of an individual. Therefore, anxiety perception and results may not show similarity in every case and situation. Thus, possible academic achievement results to be caused by anxiety may differ depending on the personal traits of individuals. For instance, due to her/his personal traits, the individual may not be anxious despite his low academic achievement. Contrarily, an individual with high academic achievement may have high state or trait anxiety. Another explanation for differing study results may be the characteristics of the course or discipline subject to academic achievement. For example, reaction of the student to chemistry or physics course or the pressure imposed on the individual by these courses and the difficulty perceived by the student in relation to these courses may create a student mood different than the moods developed in other courses. In addition, effects of other variables that may be related to academic achievement may differentiate the relationship between anxiety and academic achievement. For instance, teaching method and classroom attitudes and behaviors of the teacher may affect the relationship between academic achievement and perceived anxiety of the student. Moreover, school can be a factor differentiating the effects of student's anxiety or anxiety types on her/his academic achievement. For instance, the support offered to the student by a school with developed infrastructure and hardware opportunities may facilitate and increase academic achievement of the student. This situation may also positively affect self-confidence and, in turn, anxiety level of the student. For this reason, differences in the results of these literature studies should be considered taking into account the facilities of the related study sample group.

In this study, the ability of academic self-efficacy, student self-efficacy, state anxiety and trait anxiety variables to predict achievement in physics, chemistry, biology and math courses was detected to vary depending on course type. From the point of self-efficacy, results are seen to comply with the disposition of self-efficacy fact. This result seems to 
be in compliance with the theoretical framework of the fact of self-efficacy. As a matter of fact, Zimmerman (2000) stated that self-efficacy belief has no single disposition, rather has a multi-dimensional characteristic and, in turn, may differ according to fields. On the other hand, there is no literature study examining academic achievement on the basis of fields or courses, however, self-efficacy (Hampton \& Mason, 2003; Fettahlığlu et al., 2011) and academic self-efficacy (Yazıc1 et al., 2011; Abd-Elmotaleb \& Saha, 2013; Akomolafe et al., 2013) are detected to be predictors of academic self-efficacy in the context of general academic achievement.

In this study, academic self-efficacy and trait anxiety variables predicted achievement in physics course. Student self-efficacy and state anxiety variables, on the other hand, were not found to be significant in predicting physics achievement. Exclusion of these two variables from the model can be explained as follows: there is an almost high correlation between academic self-efficacy and student self-efficacy and, for this reason; academic self-efficacy having relatively higher effect on physics achievement plays predictor role. However, it is impossible to mention a similar relationship for state anxiety. In other words, state anxiety variable's inability to predict physics achievement does not result from its relationship with trait anxiety variable. As a matter of fact, even in cases when trait anxiety is excluded from and state anxiety is included in the model, state anxiety variable was not a predictor of physics achievement. Different results are suggested by the literature studies analyzing not all but a part of the variables included in the model adopted by the present study. For instance, in the study by Okur \& Bahar (2010), trait anxiety did not predict academic achievement. However, the results of the study by Okur \& Bahar (2010) should be considered cautiously since the concerned study addressed general academic achievement. Present study, on the other hand, addressed academic achievement on course basis. Another issue to be mentioned in the present study about prediction of physics achievement is that the relative importance of academic self-efficacy variable in predicting physics achievement was found to be higher than that of trait anxiety. This result shows that academic self-efficacy variable -having a positive content from the point of students on physics achievement- is more important than trait anxiety, an indicator of negative mood.

Only academic self-efficacy variable was found to be predictor in chemistry achievement. As in the analysis on physics course, academic self-efficacy variable having a relatively higher importance for chemistry excluded student self-efficacy variable from the model. As a matter of fact, in another study (Çetin-Dindar \& Geban, 2011), self-efficacy was found to be the variable predicting chemistry achievement. However, it is interesting that state anxiety or trait anxiety is not a predictor for chemistry achievement. It is possible to relate insignificance of anxiety variable in explaining chemistry achievement with the nature of the course (Kondakci et al., 2011). The issues and concepts constituting chemistry course content are more concrete and can be experimentally examined under laboratory conditions, which can be suggested to positively affect learning and, in turn, student's mood about the course.

Student self-efficacy variable was predictor in biology achievement. Insufficiency of academic self-efficacy variable to predict biology achievement does not result from ineffectiveness of this variable on achievement. This situation can be offered to be caused by the high correlation between the variables of academic self-efficacy and student self-efficacy. Therefore, student self-efficacy having relatively higher influence in explaining biology achievement was found to be important. In biology achievement, it is seen that self-efficacy perception developed by the student her/himself is more important than her/his perceiving her/himself academically self-efficient. It can be suggested that students have the perception that they can achieve biology course by self-efficacy. Academic efficacy perception of the student seems not to be a dominant variable in biology achievement. On the other hand, as in chemistry achievement, state and trait anxiety were found by the present study to be statistically insignificant in predicting biology achievement.

Academic self-efficacy and state anxiety were observed to be the variables predicting math achievement. Both variables had positive effect on math achievement. In also the study by Ferla, Valcke, \& Cai (2009), academic self-efficacy was found to be an important predictor of math achievement. On the other hand, it is seen that the present study found student self-efficacy non-predictor due to its high correlation with academic self-efficacy. However, no such result -to be caused by a similar type of relation- was produced by the study for trait anxiety.

\section{Conclusion}

Evaluation of the results of this study as a whole shows that it is more meaningful to make a detailed examination of academic achievement according to courses and fields. It can be suggested that addressing academic achievement as a whole on the basis of grade point average may lead to unsatisfying explanations. As a matter of fact, the present study showed that variables affecting or predicting academic achievement differ depending on course type. Therefore, it is important for the studies aimed at predicting academic achievement to consider the structure and characteristics of courses. Otherwise, examination of academic achievement as a whole may lead to ignorance of variables predicting academic achievement. This situation drastically damages validation of the model predicting achievement.

When the specific results of the study are examined, academic self-efficacy is observed to be determinant in predicting 
physics, chemistry and math achievement. Student self-efficacy perception, on the other hand, is significant in biology achievement. Examination of study results in terms of anxiety variables reveals that trait anxiety is predictor in physics achievement and state anxiety in math achievement. Study results are meaningful and interpretable. However, the results are limited to the vocational high school students constituting the scope of this study. For this reason, school type should be diversified and sampling number be increased for generalizable results.

In the light of these results, further studies should be made on following issues: Firstly, investigation of positive predictor role of trait anxiety in physics achievement and of state anxiety in math achievement; secondly, the reasons why state anxiety and trait anxiety are not predictor variables of chemistry and biology achievement; and thirdly, which variable is antecedent in its relationship with academic achievement.

\section{References}

Abd-Elmotaleb, M., \& Saha, S. K. (2013). The role of academic self-efficacy as a mediator variable between perceived academic climate and academic performance. Journal of Education and Learning, 2(3), 117-129. http://dx.doi.org/10.5539/jel.v2n3p117

Adebayo, B. (2008). Cognitive and Non-Cognitive Factors: Affecting the Academic Performance and Retention of Conditionally Admitted Freshmen. Journal of College Admission, 200, 15-21.

Akar, A., Dağ, A. D., \& Miman, M. (2014). Trait anxiety level analysis of high school students with migration in Mersin. Procedia Social and Behavioral Sciences, 113, 143-150. http://dx.doi.org/10.1016/j.sbspro.2014.01.021

Akbaş, A., \& Kan, A. (2007). Affective factors that influence chemistry achievement (motivation and anxiety) and the power of these factors to predict chemistry achievement-II. Journal of Turkish Science Education, 4(1), 10-19.

Akomolafe, M. J., Ogunmakin, A. O., \& Fasooto, G. M. (2013). The role of academic self-efficacy, academic motivation and academic self-concept in predicting secondary school students' academic performance. Journal of Educational and Social Research, 3(2), 335-342. http://dx.doi.org/10.5901/jesr.2013.v3n2p335

Altun, F., \& Yazıc1, H. (2012). Self-Concept and Academic Self-Efficacy Beliefs of Gifted Students: A Comparative Study. Mehmet Akif Ersoy University Journal of Education Faculty, 12(23), 319-334.

Bandura, A. (1977). Self-efficacy: Toward a unifying theory of behavioral change. Psychological Review, 84, 191-215. http://dx.doi.org/10.1037/0033-295X.84.2.191

Bandura, A. (1994). Self-Efficacy. In V. S. Ramachaudran (Ed.), Encyclopedia of Human Behavior (Vol. 4, pp. 71-81). New York: Academic Press.

Bulach, C. R., Malone, B., \& Castleman, C. (1995). An investigation of variables related to student achievement. Mid-Western Educational Researcher 8(2), 23-29.

Büyüköztürk, Ş. (1997). Araştırmaya Yönelik Kaygı Ölçeğinin Geliştirilmesi. Eğitim Yönetimi, 3(4), 453-464.

Carberry, A. R., Lee, H. S., \& Ohland, M. W. (2010). Measuring Engineering Design Self-Efficacy. Journal of Engineering Education, January, 71-79. http://dx.doi.org/10.1002/j.2168-9830.2010.tb01043.x

Civan, A., Özdemir, İ., Taş, İ., \& Çelik, A. (2012). Bedensel engelli ve engelli olmayan tenis sporcularının durumluk ve sürekli kaygı düzeylerinin karşılaştırılması. Selçuk Üniversitesi Beden Eğitimi ve Spor Bilim Dergisi, 14(1), 83-87.

Cupani, M., Richaud de Minzi, M. C., Perez, E. R., \& Pautassi, R. M. (2010). An assessment of a social-cognitive model of academic performance in mathematics in Argentinean middle school students. Learning and Individual Differences, 20, 659-663. http://dx.doi.org/10.1016/j.lindif.2010.03.006

Çetin-Dindar, A., \& Geban, Ö., (2011), What Affect High School Students' Chemistry Learning? Dokuz Eylül University. Institute of Education Sciences Western Anatolia Journal of Educational Sciences (WAJES), Special Issues, 439-442.

Çikrıkçi, Ö., \& Odacı, H. (2013). Investigating science high school students' metacognitive awareness and self-efficacy perceptions with respect to the some individual and academic variables. International Journal of Human Sciences, 10(2), 246-259.

Dalgety, J., \& Coll, K. R. (2006). Exploring first-year science students' chemistry self-efficacy. International journal of science and mathematics education, 4, 97-116. http://dx.doi.org/10.1007/s10763-005-1080-3

Dereli, E., Angın, E., \& Karakuş, Ö. (2012). Factors that affect the problem solving skills of preschool teacher candidates: academic achievement and types of anxiety. International Journal of Human Sciences, 9(2), 731-742.

Diseth, A. (2011). Self-efficacy, goal orientations and learning strategies as mediators between preceding and subsequent academic achievement. Learning and Individual Differences, 21,191-195. 
http://dx.doi.org/10.1016/j.lindif.2011.01.003

Durmuş̧̧elebi, M., \& Bilgili, A. (2014). Yeni (12 Yıllık) Eğitim Sistemi, Karşılaşılan Sorunlar ve Dünyadaki $\begin{array}{lllll}\text { Uygulamalardan Bazlarının İncelenmesi. Turkish } & \text { Studies, } & \text { 9(2), }\end{array}$ http://dx.doi.org/10.7827/TurkishStudies.6122

Ferla, J., Valcke, M., \& Cai, Y. (2009). Academic self-efficacy and academic self-concept: Reconsidering structural relationships. Learning and Individual Differences, 12, 499-505. http://dx.doi.org/10.1016/j.lindif.2009.05.004

Ferla, J., Valcke, M., \& Schuyten, G. (2010). Judgments of self-perceived academic competence and their differential impact on students' achievement motivation, learning approach, and academic performance. European Journal of Psychology of Education, 25, 519-536. http://dx.doi.org/10.1007/s10212-010-0030-9

Fettahlığlu, P., Güven, E., İnce, A. E., Sert Ç. A., \& Aydoğdu, M. (2011). The Effect of Science Teacher Candidates' Self-Efficacy towards Science Education on Academic Achievement. Ahi Evran University Journal of Kirşehir Education Faculty, 12(3), 159-175.

Gilles, P. Y., \& Bailleux, C. (2001). Personality traits and abilities as predictors of academic achievement. European Journal of Psychology of Education, 16(1), 3-15. http://dx.doi.org/10.1007/BF03172991

Hampton, N. Z., \& Mason, E. (2003). Learning disabilities, gender, sources of efficacy, self-efficacy beliefs, and academic achievement in high school students. Journal of School Psychology, 41, 101-112. http://dx.doi.org/10.1016/S0022-4405(03)00028-1

Heinrich, D. L. (1979). The causal influence of anxiety on academic achievement for students of differing intellectural ability. Applied Psychological Measurement, 3(3), 351-359. http://dx.doi.org/10.1177/014662167900300307

Hejazi, E., Shahraray, M., Farsinejad, M., \& Asgary, A. (2009). Identity styles and academic achievement: mediating role of academic self-efficacy. Social Psychology of Education, 12(1), 123- 135. http://dx.doi.org/10.1007/s11218-008-9067-x

Kan, A., \& Akbaş, A. (2006). Affective factors that influence chemistry achievement (attitude and self efficacy) and the power of these factors to predict chemistry achievement-I. Journal of Turkish Science Education, 3(1), 76-85.

Kemer, G. (2006). The role of self-efficacy, hope, and anxiety in predicting university entrance examination scores of eleventh grade students, Unpublished Master's Thesis, Middle East Technical University, Graduate School of Social Sciences, Ankara.

Komarraju, M., \& Nadler, D. (2013). Self-efficacy and academic achievement: why do implicit beliefs, goals, and effort regulation matter? Learning and Individual Differences, 25, 67-22. http://dx.doi.org/10.1016/j.lindif.2013.01.005

Kondakci, E. U., Aydın, Y. C., Kirbulut, Z. D., \& Beeth, M. E. (2011). Predictors of Chemistry Self-Efficacy Among College Students. European Science Education Research Association (ESERA) Conference, 113.

Kurbanoğlu, N. I., \& Akim, A. (2010). The relationships between university students' chemistry laboratory anxiety, attitudes, and self-efficacy beliefs. Australian Journal of Teacher Education, 35(8), 47-59. http://dx.doi.org/10.14221/ajte.2010v35n8.4

Kurbanoğlu, N. İ., \& Takunyacı, M. (2012). An investigation of the attitudes, anxieties and self-efficacy beliefs towards mathematics lessons high school students' in terms of gender, types of school, and students' grades. International Journal of Human Sciences, 9(1), 110-130.

Landry, C. C. (2003). Self-efficacy, motivation, and outcome expectation correlates of college students' intention certainty. Unpublished doctoral thesis, Louisiana State University and Agricultural and Mechanical College, Lafayette, USA.

Li, L. K. Y. (2012). A study of the attitude, self-efficacy, effort and academic achievement of city U studendents towards research methods and statistics. Discovery-SS Student E-Journal, 1, 154-183.

Loo, C. W., \& Choy, J. J. F. (2013). Sources of self-efficacy influencing academic performance of engineering students. American Journal of Educational Research, 1(3), 86-92. http://dx.doi.org/10.12691/education-1-3-4

Lounsbury, J. W., Fisher, L. A., Levy, J. J., \& Welsh, D. P. (2009). An investigation of character strengths in relation to the academic success of college students. Individual Differences Research, 7(1), 52-69.

McEwan, L., \& Goldenberg, D. (1999). Achievement motivation, anxiety and academic success in first year master of nursing students. Nurse Education Today, 19, 419-430. http://dx.doi.org/10.1054/nedt.1999.0327

Mohammadyari, G. (2012). Comparative study of relationship between general perceived self-efficacy and test anxiety with academic achievement of male and female students. Procedia Social and Behavioral Sciences, 69, 2119-2123. 
http://dx.doi.org/10.1016/j.sbspro.2012.12.175

Nadeem, M., Ali, A., Maqbool, S., \& Zaidi, S. U. (2012). Impact of anxiety on the academic achievement of students having different mental abilities at university level in Bahawalpur (Southern Punjab) Pakistan. International Online Journal of Educational Sciences, 4(3), 519-528.

Okur, M., \& Bahar, H. H. (2010). Learning styles of primary education prospective mathematics teachers; states of trait-anxiety and academic success. Procedia Social and Behavioral Sciences, 2, 3632-3637. http://dx.doi.org/10.1016/j.sbspro.2010.03.565

Owen, V. S., \& Froman, R. D. (1988). Development of a college academic self-efficacy scale. Paper presented at the Annual Meeting of the National Council on Measurement in Education, New Orleans, LA. (ERIC Document Reproduction Service No ED 298158).

Öner, N., \& Le C. A. (1985). Durumluk - sürekli kaygı envanteri el kitabı. İstanbul: Boğaziçi Üniversitesi Yayınları No:333.

ÖSYM (2014). http://dokuman.osym.gov.tr/pdfdokuman/2014/ygs/2014ygssayisalbilgiler03042014.pdf. Accessed 1 April 2014.

Rouxel, G. (1999). Path analyses of the relations between self-efficacy, anxiety and academic performance. European journal of psychology of education, 14(3), 403-421. http://dx.doi.org/10.1007/BF03173123

Sakız, G. (2013). Başarıda anahtar kelime: Öz-yeterlik. Uludağ Üniversitesi Eğitim Fakültesi Dergisi, 26(1), 185-209.

Sezer, F., İşgör, İ. Y., Özpolat, A. R., \& Sezer, M. (2006). Lise öğrencilerinin öz yeterlilik düzeylerinin bazı değişkenler açısından incelenmesi. Kazım Karabekir Ĕ̈itim Fakültesi Dergisi, 13, 129-137.

Şahin, H., Gülay, O. H., \& Ekici, G. (2011). Okul öncesi öğretmen adaylarının akademik öz-yeterlik düzeylerine etki eden faktörlerin değerlendirilmesi. Çağdaş Eğitim Dergisi, 36(389), 13-22.

Shavit, Y., \& Muller, W. (2000). Vocational secondary education. European societies, 2(1), 29-50. http://dx.doi.org/10.1080/146166900360710

Shkullaku, R. (2013). The relationship between self-efficacy and academic performance in the context of gender among Albanian students. European Academic Research, 1(4), 467-478.

Sikhwari, T. D. (2007). The relationship between affective factors and the academic achievement of students at the University of Venda. South African Journal of Higher Education, 21(3), 520-536.

Singh, I., \& Jha, A. (2013). Anxiety, optimism and academic achievement among students of private medical and engineering colleges: a comparative study. Journal of Education and Developmental Psychology, 3(1), 222-233. http://dx.doi.org/10.5539/jedp.v3n1p222

Sönmez, M. (2008). The Problems of Vocational and Technical Education in Turkey and the Necessity of Restructuring. Education and Science, 33(147), 71-84.

Tenaw, Y. A. (2013). Relationship between self-efficacy, academic achievement and gender in analytical chemistry at Debre Markos college of the teacher education. African Journal of Chemical Education, 3(1), 3-28.

Spielberger, C. D., Gorsuch, R. L., \& Lushene, R. E. (1970). Manuel for the State-Trait Anxiety Inventory, Palo Alto, California: Consulting Psychologist Press.

Weiser, D. A., \& Riggio, H. R. (2010). Family background and academic achievement: does self-efficacy mediate outcomes? Social Psychology of Education, 13(3), 367-383. http://dx.doi.org/10.1007/s11218-010-9115-1

Yaratan, H., \& Suphi, N. (2012). Impact of self-efficacy and learning approaches on achievement controlling for demographic variables. H.U. Journal of Education, 2, 232-243.

Yazıc1, H., Seyis, S., \& Altun, F. (2011). Emotional intelligence and self-efficacy beliefs as predictors of academic achievement among high school students. Procedia Social and Behavioral Sciences, 15, 2319-2323. http://dx.doi.org/10.1016/j.sbspro.2011.04.100

Yeşilyurt, E. (2013). Academic self-efficacy perceptions of teacher candidates. Mevlana International Journal of Education, 3(1), 93-103. http://dx.doi.org/10.13054/mije.13.12.3.1

Yılmaz, E., Yiğit, R., \& Kaşarcı, İ. (2012). A study on self-efficacy levels of primary education Students in terms of academic success and some Variables. Mehmet Akif Ersoy University Journal of Education Faculty, 12(23), 371-388.

Yokuş, T. (2013). The relationship between the state-trait anxiety levels and the academic achievement of music teacher 
candidates. International Online Journal of Primary Education, 2(1), 25-31.

Zajacova, A., Lynch, S. M., \& Espenshadet, T. J. (2005). Self-efficacy, stress, and academic success in college. Research in Higher Education, 46(6), 677-706. http://dx.doi.org/10.1007/s11162-004-4139-z

Zimmerman, B. J. (2000). Self-Efficacy: An Essential Motive to Learn. Contemporary Educational Psychology, 25, 82-91. http://dx.doi.org/10.1006/ceps.1999.1016

Zin, Z. M., \& Rafik-Galea, S. (2010). Anxiety and academic reading performance among Malay ESL learners. Pan-Pacific Association of Applied Linguistic, 14(2), 41-58.

\section{$(\mathrm{Cc}) \mathrm{BY}$}

This work is licensed under a Creative Commons Attribution 3.0 License. 